\title{
Motor skills of children with autistic spectrum disorder
}

\author{
Pavel Zikl ${ }^{1 \mathrm{a}}$, Dita Petrů ${ }^{1}$, Aneta Daňková $^{1}$, Hana Doležalová ${ }^{1}$ and Kateřina Šafaříková ${ }^{1}$ \\ ${ }^{1}$ Institute for Primary and Pre-Primary Education, Faculty of Education, University of Hradec \\ Králové, Rokitanskeho 62, Hradec Kralove, 500 03, Czech Republic
}

\begin{abstract}
The contribution contains results of a research of motor skills of children with autistic spectrum disorder. The group of children represents besides major triad of symptoms, also described difficulties in the field of motor skills. Our aim to find out what motor skills of these children are in comparison with intact population and what differences are found in individual motor items, i.e. in fine motor skills, gross motor skills and in balance. The data was gained with the use of standardized Movement Assessment Battery test for Children 2 (MABC-2). Objective testing of this group of children is relatively difficult. There were successfully tested 36 children with ASD during this phase of research. The research demonstrated evident motor disorder at $86 \%$ of children in the observed sample. Statistically significant were worse results in the field of fine motor skills compared to the results in gross motor skills and balance.
\end{abstract}

Keywords: Autistic spectrum disorder; motor skills; MABC-2; fine motor skills; gross motor skills; balance

\section{Introduction}

Autism spectrum disorders (ASD) represent a highly variable neurodevelopmental disorder that ranks among the most serious disorders of children's mental development. So called a triad of symptom is characteristic for them, i.e. disorder of social interaction, verbal and nonverbal communication disorder and a tendency toward limited, repetitive or stereotypical behaviour pattern. The ASD's displays cover a wide spectrum, from individuals with severe disabilities, who do not speak, have mental disability and their level of sociability is very low (low-functioning autism) up to individuals who have a standard intellect, communicate verbally and are able to have independent life (high-functioning autism) [9].

According to the International Classification of Diseases (ICD-10) [6] there are several individual categories classified into a group of pervasive developmental disorders, of which

\footnotetext{
a Corresponding author: pavel.zikl@uhk.cz
} 
the best known: Infantile autism (F 84.0), Atypical autism (F84.1) and Asperger syndrome (F 84.5). In the current classification of American Psychiatric Association (DSM-V) further division into partial diagnosis is not applied, there is only one disorder listed - Autism spectrum disorder (ASD) [1].

Several individual with ASD show other diseases and disorders, for example genetic diseases (20-30\%), anxiety disorders (11-84\%), epilepsy, physical variations, sleep disorders, mental retardation (20-70\%) and also disorders of motor functions. Disorders of motor coordination are widespread at all ASD and are the strongest at infantile autism. It is estimated that $60-80 \%$ of autistics have motor disorder, including hypotonia, poor planning of movement and walking on tiptoes [10]. Children with ASD have significant stress to imitate motor standard, they learn to imitate gestures and the use of objects slowly. There is also decreased motivation and overall reduced ability to learn new skills that contributes to the uneven development of motor skills [3]. The deficiencies in gross motor skills, which frequently occur at these children, are: clumsiness in overcoming obstacles, low control balance, lack of coordination, energy and muscle strength and also poor ability in control of speed movement [8].

From the wide range of difficulties that occur at children with ASD, we have focused in our research on motor activity and motor skills. The level respectively the deficit in the field of motor activity does not belong among primary symptoms of ASD, but it is one of the main factors that influence performance of activities of daily living, education and socialization of these children. From different areas of motor activities, i.e. visceral (e.g. respiratory), postural locomotors (gross motor), fine motor skills (dexterity) and oromotor skills, we have mainly focused in our research on gross motor skills and fine motor skills. The gross motor skills contain two main parts, i.e. locomotor (total body movement) and postural functions (maintainig body position). Fine motor skill is described as dexterity, skilled and it is the ability to deftly manipulate with small object under control in a small space [2].

\section{Goals and methodology}

The subject of the research was to describe levels of motor skills of children with ASD at preschool and school age. We have focused on three key areas that affect the performance of activities of daily living - gross motor skills, fine motor skills and balance. Furthermore we focused on results comparison of children with diagnosis Infantile Autism and a dg. Atypical autisms.

We have made following hypotheses:

- H1: We assume that children with autism spectrum disorder show a lower level of motor skills in comparison with the standard of intact children at the same age group.

- H2: We assume that there is a lower level of motor skills in the field of fine motor skills compared with gross motor skills at children with autism spectrum disorder.

- H3: We assume that children with autism spectrum disorder have a lower level of motor skills in the field of fine motor skills compared with balance.

- H4: We assume that children with autism spectrum disorder have a lower level of motor skills in the part of balance/stability compared with gross motor skills.

- H5: We assume that children with Infantile Autism have a lower level of motor skills compared with children with Atypical Autism. 
Sign one sample test, Student's T-test, nonparametric Mann-Whitney test had been chosen for testing the hypotheses. The distribution of probands according to age and a test score component was tested for normality by the Kolmogorov-Smirnov normality test, D'Agostino Skewness normality test, D'Agostino Kurtosis normality test, D'Agostino Omnibus normality test (the division of results of individual tests of probands can be considered as standard). A level of significance $\alpha=0,05$ had been chosen for testing.

\subsection{Description of research tool}

A standardized test MABC-2 (Movement Assessment Battery for Children) has been used for data collection, which can be considered for yet most comprehensively constructed diagnostic tool for evaluation of motor activity and identification of developmentally conditioned motor deficiency in children [4]. This test contains also standards for the Czech population aged $3-16$ years. The test is designed not only for the use in physiotherapy but allows the use by special educators, psychologists or teachers [7]. The whole test battery is divided into three basic components [7]:

- A component of manual skills (fine motor skills): evaluated by an item of unimanual coordination, item of bimanual coordination and item of unimanual graphotomotor coordination,

- A component of aiming and catching (gross motor skills): evaluated by an item of visual motor coordination in the task of catching and an item of visual motor coordination in the task of aiming.

- A component of balance: evaluated by an item of balance, item of dynamic balance, in the task of bipedal locomotion with a support and item of dynamic balance in the task of bipedal locomotion including a phase without support (jumps, hops).

The results of partial subtests of individual children have been converted into percentile range, allowing that comparison with the standard for Czech intact population of the given age. The percentiles are in the range of 1 . Up to 99 percentiles, the 50th percentile is expressed by a median performance in the population of given age. The results have been divided into three zones - no motor disorders, a risk of motor disorders, significant motor disorders (see Table 1).

\subsection{Research sample}

The research sample was consisted of a total of 36 children with autism spectrum disorder at the age of 3 to 16 years. These are the only children who were able to cooperate and completed the whole test. A preselection had been made in individual schools, where children capable of cooperation and able to pay attention throughout the test were selected. Another part of them was eliminated and also during testing (failure to complete the task or the whole test). Specific diagnoses were represented by Atypical autism in the number of 19 children, Infantile autism in the number of 16 children and one child with Asperger syndrome. Both gender groups were represented in the ratio 33:3 (boys: girls). These were children from special Kindergartens and Primary schools. 


\section{Research results}

Table 1 presents the whole test's summary of results (i.e. subtests focused on gross motor skills, fine motor skills, balance) with the classification to individual zones of motor skills level according to the test manual.

Table 1. Results of children with ASD in MABC-2 test

\begin{tabular}{lcccc}
\hline & $\begin{array}{c}\text { Total testing } \\
\text { score (TTS) }\end{array}$ & Percentile & $\begin{array}{c}\text { Number of } \\
\text { probands }\end{array}$ & $\begin{array}{c}\text { Proband's } \\
\%\end{array}$ \\
\hline $1^{\text {st }}$ Zone, no motor disorders & $>70$ & $>15$ th & 1 & $3 \%$ \\
$2^{\text {nd }}$ Zone, a risk of motor disorders & $62-70$ & $6-15$ th & 4 & $11 \%$ \\
$3^{\text {rd }}$ Zone, significant motor disorders & $<61$ & $<5$ th & 31 & $86 \%$ \\
\hline
\end{tabular}

Out of the complete sample of 36 probands only 1 proband reached a level of intact population median.

On the basis of statistical processing of the results we can state, that $\mathrm{H} 1$ has been approved. Children with autism spectrum disorder in our sample show a lower level of motor skills in compared with the standard of intact children at the same age group. Just only one child did not perceive motor difficulties, whereas $86 \%$ children had significant difficulties. Furthermore it is necessary to point out that, there were compared children who managed the test. A relatively large proportion of children could not have been tested (difficult cooperation, misunderstanding of the task, failure to complete the test) where we can also assume significant motor difficulties.

Then we were interested in the difference between results of children in individual subtests, i.e. in gross motor skills, fine motor skills and balance, to which H2-H5 hypotheses relate to. These results are described in Table 2.

Table 2. Comparison of results of individual subtests of MABC-2 test

\begin{tabular}{lcc}
\hline Standard scores & $\begin{array}{c}\text { Student's t-test } \\
\text { T value }\end{array}$ & $\begin{array}{c}\text { Mann-Whitney's } \\
\text { test } \\
\mathrm{Z} \text { value }\end{array}$ \\
\hline Fine motor skills x Gross motor skills & $-4,18$ & $-3,62$ \\
Fine motor skills x Balance & $-2,25$ & $-1,77$ \\
Gross motor skills x Balance & 1,89 & 1,66 \\
\hline
\end{tabular}

Note: Results in bold contain statistically significant difference ( $\mathrm{t}$ critical value $=2,0301 ; \alpha=0,05$ ).

Based on these calculations we can state that children in our sample reached the worst results in fine motor skills, compared with gross motor and also balance. Whereas no statistically significant difference was not demonstrated between gross motor and balance. Hypotheses $\mathrm{H} 2$ and $\mathrm{H} 3$ have been approved, not $\mathrm{H} 4$ hypotheses. The reality that children with ASD reach better results in gross motor skills, than in fine motor skills, has been observed in other studies, which used different testing methods [13, 5]. Wuang et al. [13] says that it is probably due to the fact that fine motor skills place great demands on maturity and integrity of cortical areas of the nervous system, particularly on frontopariental network. According to theoretical knowledge the fine motor skills are phylogenetically superior to gross motor skills [11]. On the other side e.g. Whyatt [12] does not clearly confirm a significant difference found in fine motor skills in his research. 
The last hypothesis (H5) was related to the differences among children with Infantile autism (16 children) and Atypical autism (20 children). There we presumed a worse result in children with Infantile autism; however this assumption was not confirmed. In both groups, the results were virtually identical (average gross score 3,99, respectively 3,95). It should be noted that these compared groups were relatively small.

\section{Discussion}

The use of standardized methods on children with ASD is always relatively difficult, as a relatively large number of children are not normally possible to be tested, therefore the research sample narrows. Excluded were mainly children with severe intellectual disability, with whom it was not possible to do this test, but we can assume that they would have reached probably even worse results than in the testing sample.

The level of cognitive abilities could have an influence on the results, which was not possible to be assessed in our sample, due to the fact that there were only nine children without intellectual disability. In the next phase of the data collection we would like to concentrate on this targeted group and to prove, if there is a statistical difference in motor skills among children with ASD with intellectual disability and without.

The worst results were reached in the component of fine motor skills (manual skills) and conversely the best mastered was the component of gross motor skills (aiming-catching). However it should be noted that during indicative qualitative evaluation, i.e. with unlimited time and support, more or less were these pupils able to manage the tasks. In the contrast of gross motor skills, where not even during unlimited time, most of the children did not manage the tasks at all.

Somewhat atypical ratio of boys and girls (33:3) was found. A higher number of boys in the group of children with ASD appears, but not so significant. Theoretically there should not be a difference in motor skills according to gender; finally as it is apparent from the test standards, which are the same for both gender groups.

\section{Conclusion}

Difficulties in motor skills are not basic symptoms of ASD and assessment of the level of motor skills is not part of the diagnostic. However a great number of children with ASD have significant difficulties. Under the 5th percentile, in the zone of significant motor skills difficulties, there were $86 \%$ of all monitored children. Test MABC-2 is a good tool for evaluation of the stage of motor difficulties, it is possible to be used at most children with ASD, who are able to do the subtest and complete the entire test. Problematic issue with the use of the test is found in a group of children with ASD with severe intellectual disability. The test divides children into three groups - children without motor difficulties, children with the prone to motor skills difficulties and children with significant motor difficulties. This division can be a good indicator to begin with therapeutic intervention or other monitoring of the child.

Certain variability occurred in the results, but we can state that generally children with ASD reached the worst results in fine motor skills, compared with gross motor skills and balance/stability. These deficits can have significant influence on children with ASD on their functional abilities, coping of activities of daily living. Monitoring of the level of motor skills and movement disorders treatment should be a part of a comprehensive rehabilitation of these children, if we want their lives to be as close as possible to the standard. 


\section{References}

1. American Psychiatric Association., Autism Spectrum Disorder. [online] [cit. 2015-59]. Available from: http://www.dsm5.org/Documents/Autism\%20Spectrum\%20Disorder\%20Fact\%20Shee t.pdf, (2013).

2. Berger, M. A., Krul, A. J., Daanen, H. A., Task specificity of Finger dexterity test. In Applied Ergonomics. Volume 40, Issue 1, Pages 145-147, ISSN: 0003-6870, (2009).

3. Čadilová, V., Thorová, K., Žampachová, Z., Katalog posuzování míry speciálních vzdělávacích potřeb. Č́st II. (diagnostické domény pro žáky $\mathrm{s}$ poruchami autististického spektra). 1. vydání, Univerzita Palackého v Olomouci. ISBN 978-80244-3054-6, (2012).

4. Henderson, S. E., Sugden, D. A., Barnett, A., L., Movement Assessment Battery for Children-2. London: Harcout Assessment, (2007).

5. Hilton, C., Wente, L., Lavesser, P. Ito, M., Reed, C., Herzeberg, G., Relationship between motor skill impairment and severity in children with Asperger syndrome. In Research in Autism Spectrum Disorders. Volume 1, Issue 4, ISSN-1750-9467, (2007).

6. ICD-10, Disorders of psychological development (F80-F89). [online] [cit. 2015-5-10]. Available from: http://apps.who.int/classifications/icd10/browse/2014/en\#/F80-F89, (2014).

7. Psotta, R., MABC-2 Test motoriky pro děti. Praha: Hogrefe - Testcentrum, (2014).

8. Schopler, E., Reichler, R., J., Lansing, M., Strategie a metody výuky dětí s autismem a dalšími vývojovými vadami. Praha: Portál. ISBN 978-80-7367-898-2, (2011).

9. Thorová, K., Poruchy autistického spektra. Praha: Portál, ISBN 80-7367-091-7, (2006).

10. Thorová, K., Poruchy autistického spektra: Dětský autismus, atypický autismus, Aspergerův syndrom, dezintegrační porucha. Praha: Portál, ISBN 978-80-262-0215-8, (2012).

11. Véle, F., Kineziologie: prrehled klinické kineziologie a patokineziologie pro diagnostiku a terapii poruch pohybové soustavy. Praha: Triton. 2006. 376 s. ISBN 80725-4837-9, (2006).

12. Whyatt, C., P., Craig, C., M., Motor Skills in Children Aged 7-10 Years, Diagnosed with Autism Spectrum Disorder. In Journal of Autism and Developmental Disorders. 42/2012. 1799-1809 s. ISSN 1573-3432, (2012).

13. Wuang, Y., Chen, C., Lin, Y., Neuropsychological predictors of everyday functioning in adults with intellectual disabilities. In Journal of Intellectual Disability Research. 1828 s. 2008 [online] [cit. 2015-5-10]. Available from: http://www.ncbi.nlm.nih.gov/pubmed/18173569, (2008). 